\title{
Factors Limiting the Range Extension of Corals into High-Latitude Reef Regions
}

\author{
David Abrego ${ }^{1, *(\mathbb{D}}$, Emily J. Howells ${ }^{1,2} \mathbb{D}$, Stephen D. A. Smith ${ }^{1} \mathbb{D}$, Joshua S. Madin ${ }^{3}$, Brigitte Sommer ${ }^{4,5} \mathbb{D}$, \\ Sebastian Schmidt-Roach ${ }^{6}$, Vivian R. Cumbo ${ }^{7}$, Damian P. Thomson ${ }^{8,9}$ (D, Natalie L. Rosser ${ }^{2}$ \\ and Andrew H. Baird ${ }^{9}$
}

check for updates

Citation: Abrego, D.; Howells, E.J. Smith, S.D.A.; Madin, J.S.; Sommer, B.; Schmidt-Roach, S.; Cumbo, V.R.; Thomson, D.P.; Rosser, N.L.; Baird, A.H. Factors Limiting the Range Extension of Corals into High-Latitude Reef Regions. Diversity 2021, 13, 632. https://doi.org/ $10.3390 / \mathrm{d} 13120632$

Academic Editors: Andrew Bauman and Nicola Browne

Received: 15 October 2021

Accepted: 29 November 2021

Published: 1 December 2021

Publisher's Note: MDPI stays neutral with regard to jurisdictional claims in published maps and institutional affiliations.

Copyright: (c) 2021 by the authors. Licensee MDPI, Basel, Switzerland. This article is an open access article distributed under the terms and conditions of the Creative Commons Attribution (CC BY) license (https:/ / creativecommons.org/licenses/by/ $4.0 /)$.
1 National Marine Science Centre, Southern Cross University, Coffs Harbour, NSW 2450, Australia; emily.howells@scu.edu.au (E.J.H.); steve.smith@scu.edu.au (S.D.A.S.)

2 Centre for Sustainable Ecosystem Solutions, School of Earth, Atmospheric and Life Sciences, University of Wollongong, Wollongong, NSW 2522, Australia; narosser@uow.edu.au

3 Hawai'I Institute of Marine Biology, University of Hawai'I at Manoa, Kane'ohe, HI 97644, USA; jmadin@hawaii.edu

4 School of Life Sciences, University of Technology Sydney, Sydney, NSW 2007, Australia; brigitte.sommer@uts.edu.au

5 School of Life and Environmental Sciences, The University of Sydney, Sydney, NSW 2006, Australia

6 Red Sea Research Center, King Abdullah University of Science and Technology, Thuwal 23955-6900, Saudi Arabia; sebastian.schmidtroach@kaust.edu.sa

7 Department of Biological Sciences, Macquarie University, Sydney, NSW 2109, Australia; vivian.cumbo@gmail.com

8 Commonwealth Scientific and Industrial Research Organisation, Oceans and Atmosphere, Crawley, WA 6009, Australia; Damian.Thomson@csiro.au

9 ARC Centre of Excellence for Coral Reef Studies, James Cook University, Townsville, QLD 4811, Australia; andrew.baird@jcu.edu.au

* Correspondence: david.abrego@scu.edu.au

Abstract: Reef-building corals show a marked decrease in total species richness from the tropics to high latitude regions. Several hypotheses have been proposed to account for this pattern in the context of abiotic and biotic factors, including temperature thresholds, light limitation, aragonite saturation, nutrient or sediment loads, larval dispersal constraints, competition with macro-algae or other invertebrates, and availability of suitable settlement cues or micro-algal symbionts. Surprisingly, there is a paucity of data supporting several of these hypotheses. Given the immense pressures faced by corals in the Anthropocene, it is critical to understand the factors limiting their distribution in order to predict potential range expansions and the role that high latitude reefs can play as refuges from climate change. This review examines these factors and outlines critical research areas to address knowledge gaps in our understanding of light/temperature interactions, coral-Symbiodiniaceae associations, settlement cues, and competition in high latitude reefs.

Keywords: climate change; coral-algal interactions; high-latitude reefs; Solitary Islands

\section{Introduction}

A decline in the species richness of tropical marine organisms at increasing distances from the centre of biodiversity in the Indo-Australian Archipelago is one of the most prominent patterns in biogeography [1,2]. The gradual attenuation in species richness of hermatypic scleractinian corals both north and south from the Indo-Pacific hotspot of coral reef biodiversity is particularly striking [3,4]. Numerous hypotheses encompassing physical or biological factors have been put forward to account for these latitudinal patterns. Dana [5] first noted the correlation between species richness and temperature, hypothesising that the establishment of viable populations on high latitude reefs might be impeded by reduced growth, fecundity, or recruitment in response to sub-optimal temperatures. Other environmental factors hypothesised to limit the latitudinal distribution of reef corals 
include light [6] (but see [7]), sediments [3], hydrodynamics [3,8], and aragonite saturation state [9]. In contrast, Johannes et al. [10] suggested that the latitudinal limits of coral reef development were determined by competition between macro-algae and corals. Specifically, Johannes et al. [10] hypothesised that macro-algae would be favoured at high latitudes by high nutrient concentrations and by reduced grazing pressure. Surprisingly, neither of these hypotheses have been explicitly tested. More recent work has demonstrated the importance of allelo-chemicals and herbivory in mediating coral-algal interactions (e.g., [11,12]) and these factors might also be involved in limiting coral latitudinal distributions.

In addition to these established hypotheses, latitudinal limits of tropical corals might also be influenced by the availability of suitable settlement cues, such as specific species of crustose coralline algae that are required to induce larval settlement in many tropical coral species [13,14]. Furthermore, reef building corals form an obligate symbiosis with microalgae of the family Symbiodiniaceae [15], and these associations are often highly specific [16-18]. Consequently, range limits of coral species may be determined by the availability of suitable symbionts $[19,20]$. Establishing specific environmental limits to the distribution of corals is critical for understanding the likely effects of increasing temperature and ocean acidification associated with global climate change. Although there may be limits to coral growth at latitudinal extremes (e.g., fixed thresholds of aragonite saturation), gradual latitudinal attenuation in species richness points to species-specific environmental tolerances or strong selective pressures on species composition.

Trait-based analyses of community composition are increasingly being used to reveal key drivers of biogeographical patterns [21-23] but the role of life history traits in influencing coral biogeography has yet to be fully explored [24]. An analysis of the effects of life history traits on latitudinal attenuation of corals along the east coast of Australia, indicates an important role for temperature, as well as the types of habitat available south of the Great Barrier Reef (GBR) [8]. Life history traits correlated with environmental tolerance, including depth range and ability to tolerate both clear and turbid waters, were strong predictors of the probability of a species to occur south of the GBR [8]. Similarly, species that regularly occur in non-reef settings (beyond-reef species) and species that are attached to the substratum were more likely than reef species or unattached species to occur south of the GBR [8]. Traits associated with dispersal ability, such as mode of larval development and egg size [25] were not important, implying that distance in itself is not a barrier to dispersing south of the GBR. However, recent work suggests that some high latitude locations, such as the Solitary Islands, are indeed isolated from the closest tropical coral reef regions, not by distance but by the trajectory of the East Australian Current [26].

The range limits of marine organisms are not static. For instance, many coral species have contracted their range northwards since the late Pleistocene on the west coast of Australia [27]. Furthermore, tropical reefs have not always been the hotspots of species richness they are today. In the last glacial maximum (LGM), coral species richness was lower at the equator when compared to higher latitudes [28]. Interestingly, environmental conditions prevailing at that time were similar to those projected to occur in the near future [28]. Consequently, high latitude regions might become important refuges for many tropical species as SST rise in response to global warming [27,29-31]. Indeed, many tropical marine species are already responding to recent rises in global sea surface temperatures by expanding their ranges pole-ward. For example, in Florida [32] and Japan [33], a number of common tropical Acropora species have been expanding their range pole-ward over the last few decades. In contrast, there have been few changes in the assemblage structure of coral in eastern Australia [26,34]. In addition, recent work suggests that successful immigrants will be those with broad environmental tolerance and able to withstand high-energy non-reef environments characteristic of some high latitude reefs [8,22,35].

Tropical coral reefs are in crises, facing threats from both continuing human misuse and climate change [36]. The key to projecting the likely changes in coral range distributions in response to climate change is to explore the processes limiting coral distributions in the present. In this review, we revisit the ideas seeking to explain what limits latitudinal range 
expansion of coral species to show that experimental support for much of the conventional wisdom is lacking (e.g., competition with macro-algae; dispersal) and outline promising areas for future research

\section{Physical Factors}

\subsection{Temperature}

Temperature decreases poleward and is considered a primary driver of the latitudinal distribution of reef building corals $[4,9,37,38]$, with reef formation typically confined to regions with annual minimum temperatures of $\geq 18^{\circ} \mathrm{C}$ [9]. Nevertheless, non-reef-forming coral communities extend to high latitudes in both hemispheres where they withstand winter temperatures well below $18^{\circ} \mathrm{C}$ and considerably wider temperature ranges than in the tropics. Average temperature masks these seasonal extremes and fluctuations at high latitudes and recent studies show that trends in average temperature only partly explain poleward range dynamics of corals $[39,40]$. For instance, correlative studies from Japan [4] and Australia [40] identified cold stress as a key limiting factor on high-latitude reefs, with minimum temperature tolerance variable among species and regions $[4,40,41]$. This highlights that even as average temperatures rise, minimum temperatures might still limit tropical corals from establishing populations in the subtropics [40,42]. Indeed, severe cold stress can impair metabolic processes and photosynthetic efficiency and cause photodamage, coral bleaching and mortality [43-45]. For example, in the Florida Keys $\left(25^{\circ} \mathrm{N}\right.$; [44]) and in Tosa Bay, Japan ( $33^{\circ} \mathrm{N}$; [46]), protracted cold spells of below $12{ }^{\circ} \mathrm{C}$ and $15{ }^{\circ} \mathrm{C}$, respectively, have led to unprecedented mass bleaching and mortality. The Tosa Bay study also highlights that despite above-average increases in winter temperatures $\left(>1.5^{\circ} \mathrm{C}\right.$ in the past century) and coral expansion in recent decades, severe cold events can dramatically reduce coral populations in warming hotspots [46].

In addition to thermal extremes, high seasonality and short-period temperature fluctuations also influence physiological performance [47] and coral range dynamics [40] in subtropical settings. In the Solitary Islands region ( $\left.31^{\circ} \mathrm{S}\right)$ for example, Malcolm et al. [48] recorded temperature changes of up to $6.5^{\circ} \mathrm{C}$ within less than $24 \mathrm{~h}$ due to the variable encroachment of the East Australia Current (EAC) and/or colder intrusions of coastal waters. These short-term extreme temperature fluctuations affect performance because of the high energetic costs associated with acclimation to changing conditions, especially in environments where corals are already close to thermal thresholds [49]. McIlroy et al. [47] examined the annual thermal performance of host, symbiont and holobiont physiology of five coral species in Hong Kong (where annual SST ranges between $14.7^{\circ} \mathrm{C}$ and $32.4{ }^{\circ} \mathrm{C}$ ) and found that although corals were able to persist through the seasonal lows, the relatively short time spent at any one temperature meant that corals operated at suboptimal performance approximately $50 \%$ of the year. These examples highlight the complex dynamics of thermal regimes at high latitudes and that further research on coral thermal performance is needed to predict coral range dynamics in response to climate change $[40,50]$.

\subsection{Light}

Most hermatypic scleractinian corals form an obligate symbiosis with photosynthetic algae. Consequently, most species depend, in part, on sun-light to power metabolism [51]. This dependence on light restricts most coral species to the photic zone in the world's oceans-defined as the depth at which light levels reach 1\% of the surface irradiance. Light irradiance also varies predictably with latitude and high latitude regions typically have lower levels of light, particularly during winter due to the high angle of incidence between sunlight and the ocean surface (e.g., [40]). Within the photic zone, species richness varies predictably with depth, with a peak in richness at intermediate depths [52,53]. Although the factors that cause this hump shaped distribution with depth remain elusive, it is possible that light plays an important role in the latitudinal attenuation of species richness. For example, species that can associate with algal symbionts with a greater capacity to function at low light irradiance [54] might have an advantage in the low light environments that 
occur at high latitudes. Alternatively, species that occur at higher latitudes might have a greater capacity to switch to heterotrophic feeding [55] or greater capacity to alter their morphology to more effectively harvest light $[56,57]$.

Muir et al. [6] recently proposed that low winter light levels limit the latitudinal distribution of corals. The maximum depth of occurrence of staghorn coral assemblages was shallower at high latitude and correlated most strongly with low winter light levels. However, in a re-analysis of these data, Madin et al. [7] found that very few of the 104 species included in Muir et al.'s [6] analysis follow this trend. In addition, the species missing from high latitude sites were species found at depth in the tropics. This strongly suggests that difference in light availability are not driving this pattern. The preferred light environments for all deep-water tropical species are present in temperate locations; they just occur at shallower depths. If anything, tropical shallow-water species should be limited by low winter light, but the decline in richness in this group was less pronounced than for deep- and mid-depth species [6]. In summary, more research on the role of light in limiting the latitudinal distribution of reef corals is required. Evidence so far indicates varied responses among taxa that are likely species-specific $[7,40,58]$.

\subsection{Aragonite Saturation}

Declining aragonite saturation $(\Omega)$ as a result of increased concentration of carbon dioxide is another potentially limiting factor on the latitudinal distribution of corals [9]. When $\mathrm{CO}_{2}$ from the atmosphere dissolves in seawater, it decreases the $\mathrm{pH}$, the $\mathrm{CO}_{3}{ }^{2-}$ concentration, and the carbonate $\left(\mathrm{CaCO}_{3}\right)$ saturation state $(\Omega)$, thereby inhibiting calcification of many organisms including corals and crustose coralline algae. The primary effects of declining calcification on corals include increased skeletal porosity resulting in weaker skeletons [59-61], reduced linear extension rates or increased susceptibility to erosion [62]. However, experimental evidence for reduced extension rates and increased susceptibility to erosion remains limited (see $[59,61])$. Secondary effects of declining aragonite saturation include reduced rates of production of $\mathrm{CaCO}_{3}$ sediments [63], reduced availability of suitable coral settlement cues due to reductions in the abundance of crustose coralline algae [64] and increased competition between corals and non-calcifying reef organisms [65]. In addition, acidification may aggravate biogenic carbonate dissolution by endolithic algae, increasing micro-bioerosion, and further undermining skeletal integrity of corals [66,67]. As surface water aragonite saturation levels continue to decline, it is hypothesised that optimal conditions for calcification will continue to contract toward the equator, potentially resulting in weaker skeletons and limiting the geographic range of many corals to low-latitudes [68].

The capacity of declining aragonite saturation levels to limit the future latitudinal distribution of corals will largely depend upon the magnitude of the change in aragonite state and the response of corals to these changes. Global average aragonite saturation in tropical surface waters is currently $4.0 \Omega$ and is predicted to decrease $30 \%$ by 2065 (to $3.1 \Omega$ ), causing reductions in $\mathrm{CaCO}_{3}$ production of $14 \%$ to $30 \%$ [69]. However, many uncertainties exist around the likely magnitude of the change in aragonite states and the response of individual taxa. Recent modelling by the Intergovernmental Panel on Climate Change suggests that most tropical and sub-tropical surface waters are likely to sustain a supersaturated aragonite state $(>3.1 \Omega)$ until 2100 [70], resulting in likely reductions in $\mathrm{CaCO}_{3}$ production in corals of only $10 \%$ [71]. Taxa-specific responses of corals to changes in aragonite saturation [72-74] and the ability of some deep-water corals to successfully live and grow in low aragonite saturation environments (e.g., $\Omega<1$; [75]) also suggest aragonite saturation is only part of the equation and that some coral species can adapt to low aragonite saturation states $(<3.1 \Omega)$. However, declining aragonite saturation may act synergistically with declining oxygen levels and increasing temperatures to cause ecosystem regime shifts $[76,77]$ to limit the future latitudinal distribution of corals. 


\subsection{Sediments}

Sedimentary regimes are the result of associations between sedimentation, turbidity, light availability, and substrate-type, and these regimes influence the distribution of reef development and coral assemblages, from local depth restrictions to broad-scale biogeography $[3,78]$. Sedimentary regimes are also thought to be responsible for delineating the southern limit of the GBR [3]. Widely separated locations with comparable sedimentary regimes have a greater coral assemblage similarity than adjacent locations with different sedimentary regimes [3,79]. Scleractinian-dominated "turbid water" assemblages on terrigenous substrates differ from "clear water" assemblages on carbonate platforms, as some species cope better than others with high turbidity and sedimentation and lower light levels [80]. For example, coral communities of the north-west shelf of Western Australia have a greater affinity to those of the outer GBR than they have to the adjacent WA mainland coast. The offshore reefs of the east and west coasts are carbonate platforms with clear water, while the onshore reefs have turbid environments dominated by terrigenous substrates. Veron [3] noted that this gives rise to a pseudo-latitudinal attenuation effect, where inshore communities tend to resemble high-latitude locations rather than adjacent offshore locations, as a result of their shared terrigenous substrates, high turbidity and low light environments. However, this hypothesis remains to be tested quantitatively.

Turbidity, and the associated loss of light penetration, has been hypothesized to limit the distribution of reef building corals on some high latitude reefs [3,42]. High levels of suspended sediment can smother corals causing mortality [81], decrease coral fertilization rates [82], and reduce the amount of light available for photosynthesis [83], and heavy sedimentation is associated with lower coral cover, fewer species and lower growth rates [78]. Therefore, highly turbid environments were previously considered to be unsuitable for coral reef development. However, recent field investigations have documented highly diverse and thriving coral reefs in regions characterized by very high turbidity and low light conditions, such as the nearshore environments of the GBR [84], the Bonaparte Archipelago in Western Australia [85], and South Atlantic reefs along the coast of Brazil [86]. These highly turbid environments might serve as important refuge for reefbuilding corals, because the high turbidity increases the intensity of light scatter, thereby reducing the solar irradiance and thermal stress on corals $[84,85,87]$. The existence of diverse coral assemblages in very turbid water (Figure 1) indicates that high turbidity (and its associated loss of light penetration) does not on its own limit the latitudinal distribution of coral reefs. Turbidity also contributes to heterotrophic nutrient availability and may benefit some corals [88-91]. If turbidity plays a role in latitudinal attenuation, it might be that a synergistic effect of decreased light availability from the angle of light at higher latitudes, together with turbidity, contributes to loss of light penetration and latitudinal attenuation of coral reefs. 


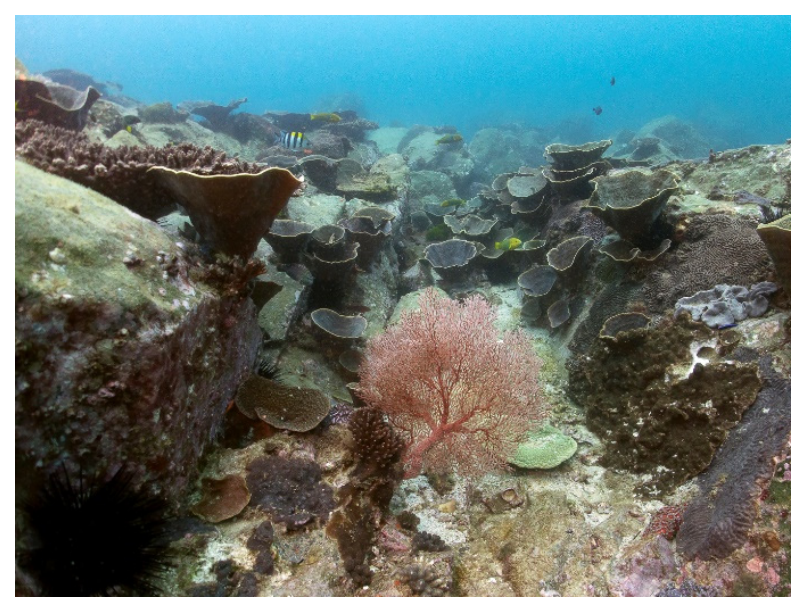

(A)

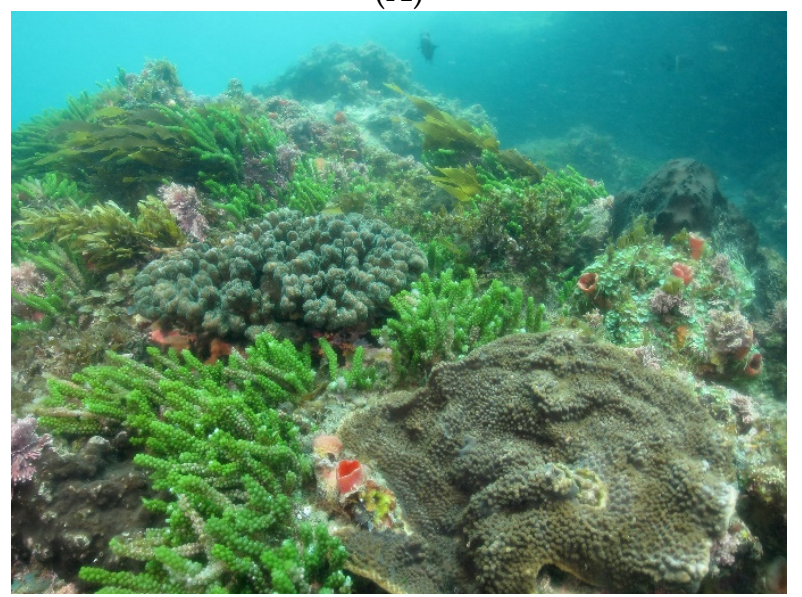

(C)

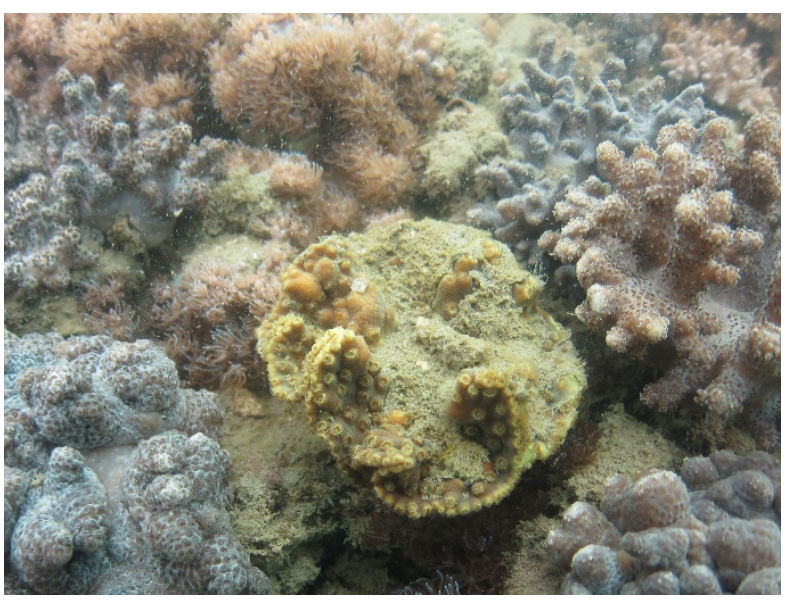

(B)

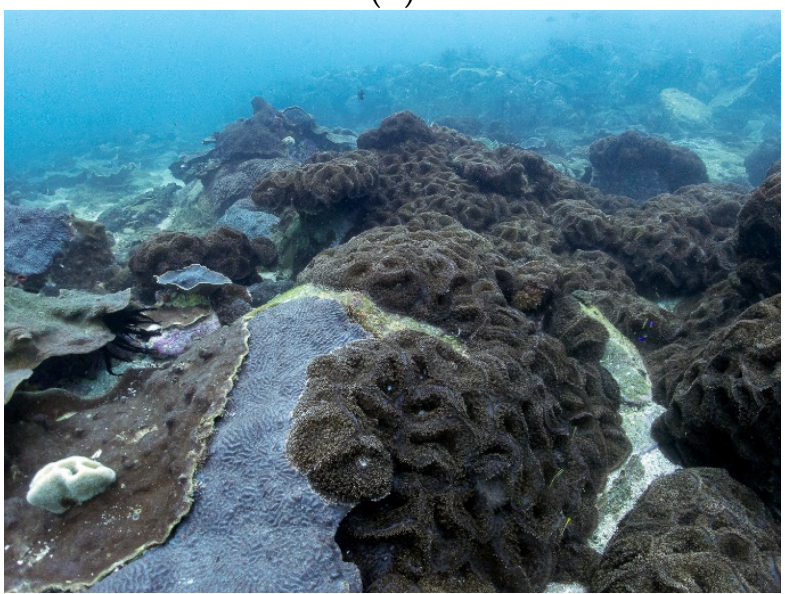

(D)

Figure 1. Subtropical coral assemblages are typically composed of a diversity of unique species (A). These assemblages are faced with environmental and biological challenges which may limit the potential of tropical scleractinian species to expand their ranges poleward as oceans warm. For example, smothering from high sediment loads (B) and competition with macroalgae (C) and other invertebrates (D). Photo credits: A, South West Solitary Island NSW, Stephen Smith; B, Hervey Bay QLD, Brigitte Sommer; C, Woolgoolga NSW, Brigitte Sommer; D, South West Solitary Island NSW, Stephen Smith.

\subsection{Nutrients}

High latitude waters are generally more nutrient-rich than those at low- and midlatitudes because their colder surface waters result in a weaker vertical density gradient which allows for greater mixing with nutrient-rich deeper waters [92]. Nutrient-rich water at high latitudes is thought to favour the growth and dominance of macroalgae over coral [10]. High algal cover can further prevent corals from establishing viable populations through further enriching the surrounding waters with nutrients and through increased bioerosion. For example, in the high latitude reefs of the Houtman-Abrolhos Islands, Western Australia, $82 \%$ of transects are dominated by macro algae [10]. This reef system has significantly higher concentrations of nitrates and dissolved inorganic phosphorus (DIP) compared to low latitude reefs [10]. It has been hypothesized that nutrient enrichment within this reef system is driven by large waves tearing macro algae from stands along the reef margins which are then deposited inside the reef complex where remineralization occurs thereby elevating the nitrate and DIP concentrations [93]. Elevated concentrations of nitrates decrease coral growth rates [94] and suppress the dependence of calcification on aragonite [95]. Very high DIP concentrations also decrease coral calcifications [96,97] but elevated levels of DIP $(3 \mathrm{uM})$ might help corals maintain their symbionts and enhance translocation and retention of carbon to hosts during heat stress [98]. Therefore, although very high concentrations of both nutrients are likely impeding corals' ability to form the 
primary framework for reef substructure, the processes involved in nutrient allocation under conditions of stress and in marginal environments still require further research.

\subsection{Hydrodynamics}

Given their dependence on light, reef building corals tend to occupy shallow regions of the ocean where hydrodynamic processes are most variable and destructive [52,99]. Hydrodynamic processes are essential to all aspects of coral life. Large-scale currents disperse larvae connecting populations [100], and fine-scale eddies entrain larvae in the reef without which larvae struggle to settle [101,102]. At the colony scale, water motion reduces the viscous boundary layer [99], improving diffusive processes [103], heterotrophic feeding [104] and growth [105]. Drag and inertial forces break and dislodge colonies [106], reducing competitive dominance [107,108], aiding in asexual propagation [109-111], and facilitating reef accretion [112] and reef strength [113].

Despite the importance of water motion to coral biology and ecology, few species flourish in areas with high levels of water motion [114]. Even at latitudes conducive to reef accretion, hydrodynamically exposed habitats have lower rates of recruitment [115-117], higher rates of colony damage and dislodgement [106,118], reduced growth rates [119], and tend to be dominated by species that can form encrusting or digitate morphologies [114]. At latitudes beyond where reefs accrete, there are fewer structures that attenuate wave energy and so corals are typically found in small areas on the protected sides of islands and headlands [22,120,121], or in bays and inlets [122]. Magnifying this lack of protective reef barriers, oceanic wave energy tends to be higher further from the tropics [123]. There is therefore a precipitous decline in species richness where reef growth ceases, which is followed by a continual decline with latitude $[3,8]$. Predictions of future storm frequencies and intensities [124] will subject these populations to periods of high wave energy, potentially decreasing the number of coral species able to persist at high latitude.

\section{Biological Factors}

\subsection{Larval Dispersal}

The subtropical coral reef populations of Eastern Australia have varying degrees of isolation from those on the GBR $[125,126]$. For example, while low levels of genetic subdivision in populations of Goniastrea australensis indicate frequent exchange of larvae, Pocillopora populations were highly isolated from their northern counterparts with a population break occurring between Cape Byron and the Solitary Islands, NSW [127]. Later work attributed the high levels of isolation to the existence of a divergent subtropical species, Pocillopora aliciae [128]. Although genetic studies provide some evidence for occasional migration of tropical Pocillopora damicornis to the Solitary Islands, frequent exchange between the GBR and the Solitary Islands can be excluded [129]. High levels of isolation and genetic structure in some coral populations are surprising considering the strong southward-directed East Australian Current (EAC) and maximum larval duration of several weeks [101,130]. However, modelling of ocean currents suggested very low probabilities of larval dispersal from the GBR to the Solitary Islands as the EAC flows further offshore [26]. This could explain the high levels of isolation. In contrast to the coastal Solitary Islands populations, low but frequent connectivity was identified for P. damicornis among GBR locations and the subtropical Elizabeth Reef and Middleton Reef located approximately $400 \mathrm{~km}$ offshore the Solitary Islands [129], suggesting that regular long-distance larval dispersal is possible. These reefs are strongly affected by the EAC, facilitating low but frequent levels of migration [129]. In contrast, populations on Lord Howe Island, an offshore reef system located further south of Elizabeth Reef and less influenced by the EAC, is highly isolated with high population structures across multiple species $[126,129,131]$. Overall, the complex population structures among these peripheral coral reef locations suggest limited dispersal strongly driven by ocean currents. 


\subsection{Settlement Cues}

Corals have a motile larval stage that ensures dispersal and must be followed by settlement onto the reef. Settlement is a complex developmental process that includes metamorphosis and successful attachment to benthic surfaces. Settlement is inducted by chemical cues associated with crustose coralline algae (CCA, $[13,132,133])$, their bacterial communities [134-137], and biofilms [138,139]. Although the sources of these cues are diverse, there is substantial variation in the inductive responses of corals to these cues. For example, among crustose coralline algae, Titanoderma prototypum is a very potent inducer, while Neogoniolithon fossleii is a very poor one for some coral species $[13,136,140]$. Although the role of crustose coralline algae or their bacterial communities as settlement cues of some corals is reasonably well established in the tropics, less is known about their role in subtropical and marginal environments. Low recruit numbers at high latitude reefs [141,142] might reflect a lower abundance of settlement cues, low larval supply, or low recruit survival. Testing the inductiveness of CCAs from these reefs will help tease these competing explanations apart. An important first step is to document the diversity of the CCAs from these environments using consistent distinguishing features and appropriate genetic markers $[143,144]$.

\subsection{Photosymbiosis}

Reef building corals have co-evolved partnerships with dinoflagellates belonging to the family Symbiodiniaceae [18]. Most broadcast-spawning corals (75\% of all species) uptake Symbiodiniaceae from the environment they recruit to and a minority of species, mostly brooders, transmit Symbiodiniaceae maternally [24]. In both cases, coral species generally only partner with a narrow subset of the Symbiodiniaceae species present at a given location [145], yet Symbiodiniaceae communities vary considerably across environmental gradients, including latitude [146]. In the South China Sea, the same set of five coral species exhibit a distinct shift to increasing abundance of type C1 (Cladocopium) Symbiodiniaceae with increasing latitude (from $9-22^{\circ} \mathrm{N}$ ) and this was most pronounced in coral species with environmental versus maternal acquisition of symbionts [147]. In Eastern Australia, Cladocopium types in seven coral species spanning environmental and maternal symbiont acquisition at Lord Howe Island $\left(31^{\circ} \mathrm{S}\right.$; [20]) are distinct from conspecifics at the GBR to the north $\left(17-23^{\circ}\right.$ S; $[146,148]$; see also [149] for comparable patterns in a sea anemone). Across a broader latitudinal range (18-35 ${ }^{\circ}$ S), Plesiastrea versipora exhibits a latitudinal change in Symbiodiniaceae communities dominated by Cladocopium at tropical and subtropical latitudes to Brevolium at temperate latitudes [150]. In Western Australia, dominant Symbiodiniaceae in high latitude corals $\left(28-33^{\circ} \mathrm{S}\right)$ were distinct from those at lower latitudes $\left(20^{\circ} \mathrm{S}\right)$ in several conspecific comparisons and included distinct Cladocopium types and an absence of Durusdinium at high latitude [151]. In a separate study, distinct Cladocopium OTUs were also observed in acroporid corals between high (28-29 $\mathrm{S})$ and low $\left(13-14^{\circ} \mathrm{S}\right)$ latitude reefs in Western Australia [152]. Furthermore, in south-eastern Africa, Cladocopium types in Stylophora pistillata shift from low to high latitude (18-31 ${ }^{\circ}$ S; [153]). An important caveat is that some of these latitudinal patterns of association may be influenced by issues delineating species boundaries in coral host and symbiont taxa $[15,154]$. Indeed, the host and symbiont associations are likely to be more species-specific than suggested by these latitudinal studies (e.g., [18,155]).

Latitudinal variation in Symbiodiniaceae communities is largely attributed to physiological differences among symbiont taxa, including tolerance of high and low temperatures $[151,156]$, as well as co-varying environmental factors, such as light, salinity, and chlorophyll [147]. However, there is a lack of information on the comparative physiology (including metabolic rates) of Symbiodiniaceae species found in conspecific hosts across latitudinal gradients. Latitudinal variation in Symbiodiniaceae communities might also be driven by their lower potential to disperse among reefs relative to the larval stages of their coral hosts (reviewed in [17]). Consequently, the diversity of Symbiodiniaceae might be reduced in high latitude marginal reefs due to environmental selection for particular 
species and types or limited potential for Symbiodiniaceae cells to disperse and recruit over large distances. For example, Chen et al. [147] documented a decline in the number and diversity of ITS2 OTUs with increasing latitude across several conspecific corals. Additionally, Wicks et al. [20] observed that Symbiodiniaceae ITS2 types that were usually distinct in coral species with horizontal versus maternal symbiont acquisition were shared at high latitude reefs on Eastern Australia (Lord Howe Island), which suggests that the environmental diversity of beneficial Symbiodiniaceae types may be limited.

Although coral species appear to partner with a diversity of Symbiodiniaceae across their range, there are evolutionary constraints to the flexibility of host-Symbiodiniaceae pairings within coral species demonstrated by inoculation experiments [157] and environmental variation in established symbioses $[129,158]$. Thus, it is possible that the distinct composition and lower genetic diversity of Symbiodiniaceae at high latitudes reduces the availability of mutualistic symbionts for some coral species. The make-up of early coralSymbiodinaceae associations has important implications for post settlement fitness (e.g., growth, survival, and thermal tolerance, $[159,160]$ ) and constraints on symbiont diversity or host flexibility will limit the success of these pairings.

Corals also form complex associations with other microbial taxa, including bacterial symbionts (reviewed in [161,162]), and these likely contribute to the success of corals in different environmental niches $[163,164]$. For example, a diversity of distinct bacterial taxa in Pachyseris speciosa at mesophotic depths is hypothesised to aid in nutrient acquisition in light-depleted environments [163]. However, insufficient knowledge of the functional roles, host specificity, and latitudinal distribution and availability of non-Symbiodiniaceae microbes precludes speculation of any role they may play in constraining the range expansion of tropical corals.

\subsection{Competition}

Competition with macroalgae, both for settlement sites and by overgrowth, was one of the early hypotheses to explain the lack of coral presence and reef accretion with increasing latitude $[10,38]$. Although evidence from experiments using settlement panels demonstrate a strong effect on post-settlement survival of corals [165], evidence of competitive overgrowth of established coral colonies is generally lacking for undisturbed communities (but may occur under the influence of increased nutrient load or sedimentation-e.g., [166]), especially in combination with low flow/water motion regimes [167]. Macroalgae dominates the benthos at nearshore sites in many high latitude regions (e.g., [29,120]), with visual evidence of coral/algal interactions (Figure 1), but medium-term studies indicate limited replacement of coral by algae [168]. Moreover, the recent general loss of macroalgae in response to climate change-driven increases in herbivory (e.g., [169]) means that instances of coral/algal interactions are likely to have declined over the same temporal scale as the increased documentation of range-extensions for many taxa (e.g., heterobranch molluscs [170]). Transition probabilities calculated from repeated assessments in fixed quadrats in subtropical eastern Australia further indicated a low probability of replacement by other benthic taxa for all major categories of coral at most mid-shelf sites (Smith SDA, unpublished data). Although competitive interactions with aggregations of tube-building polychaete worms led to higher replacement values at some sites [168,171,172], these interactions generally occurred over small spatial, and short temporal, scales. Similarly, spatially and temporally restricted interactions with corallimorpharians (Figure 1) have also been reported to lead to loss of coral on marginal reefs [173,174].

\section{Conclusions}

High latitude reefs hold potential as refuges for corals under climate change $[27,29]$ but assessing this potential requires a better understanding of traits that enhance the fitness of corals living in such stressful or sub-optimal environments [9,30,31]. Light and temperature are key environmental factors that require more research, particularly with respect to how these factors vary in space and time and how species respond to extreme 
values. The role of sediment and hydrodynamic regimes in limiting species abundances, and how these factors may combine to create complex niches are other important areas for future research.

Biological interactions that might limit coral species abundance on high-latitude reefs include symbionts and larval settlement cues. Despite a wealth of literature on coral-Symbiodiniaceae symbiosis in the tropics, our understanding of these biological interactions on high latitude reefs is limited. Do corals have access to the right type of symbionts on high latitude reefs? Insights can be gained using well-established experimental approaches. For instance, non-symbiotic coral larvae can be exposed to environmental sources of Symbiodiniaceae from high latitude locations (e.g., from sediments [175-177], or other environmental sources) to measure variation in the rate of establishment and development of the resulting host-Symbiodiniaceae partnerships (e.g., growth [178]; thermal tolerance [179]). Similarly, our understanding of the capacity for larval recruitment to high latitude reefs will benefit from a systematic evaluation of coral settlement cues on these reefs. For example, crustose coralline algae are common and abundant on these reefs but it is not clear if inductive species are present [13], or in sufficient abundance for larvae to detect these cues. Finally, potential competitive interactions that limit coral abundances on high latitude reefs require more attention, in particular from other invertebrates and macro algae.

Author Contributions: Conceptualization, A.H.B. and D.A.; writing-original draft preparation, all authors; writing-review and editing, all authors; funding acquisition, A.H.B. All authors have read and agreed to the published version of the manuscript.

Funding: This research and the APC was funded by the Australian Research Council Centre of Excellence for Coral Reef Studies Grant number CE140100020.

Institutional Review Board Statement: Not applicable.

Data Availability Statement: Not applicable.

Acknowledgments: E.J.H. was supported by a Vice Chancellor's Postdoctoral Research Fellowship from the University of Wollongong. B.S. was supported by a Chancellor's Postdoctoral Research Fellowship from the University of Technology Sydney and a University of Sydney Fellowship.

Conflicts of Interest: The authors declare no conflict of interest.

\section{References}

1. Bellwood, D.R.; Hughes, T.P.; Connolly, S.R.; Tanner, J. Environmental and geometric constraints on Indo-Pacific coral reef biodiversity. Ecol. Lett. 2005, 8, 643-651. [CrossRef]

2. Stehli, F.G.; Wells, J.W. Diversity and Age Patterns in Hermatypic Corals. Syst. Biol. 1971, 20, 115-126. [CrossRef]

3. Veron, J.E.N. Corals in Space E Time. The Biogeography E Evolution of the Scleractinia; Cornell University Press: Ithaca, NY, USA, 1995; p. 321.

4. Veron, J.E.N.; Minchin, P.R. Correlations between sea surface temperature, circulation patterns and the distribution of hermatypic corals of Japan. Cont. Shelf Res. 1992, 12, 835-857. [CrossRef]

5. Dana, J. On the temperature limiting the distribution of coral reefs. Am. J. Sci. 1843, 45, 130-131.

6. Muir, P.R.; Wallace, C.C.; Done, T.; Aguirre, J.D. Limited scope for latitudinal extension of reef corals. Science 2015, 348, 1135-1138. [CrossRef]

7. Madin, J.; Allen, A.; Baird, A.; Pandolfi, J.; Sommer, B. Scope for latitudinal extension of reef corals is species specific. Front. Biogeogr. 2016, 8, e29328. [CrossRef]

8. Mizerek, T.L.; Baird, A.H.; Beaumont, L.J.; Madin, J.S. Environmental tolerance governs the presence of reef corals at latitudes beyond reef growth. Glob. Ecol. Biogeogr. 2016, 25, 979-987. [CrossRef]

9. Kleypas, J.; McManus, J.; MeÑEz, L. Environmental Limits to Coral Reef Development: Where Do We Draw the Line? Am. Zool. 1999, 39, 146-159. [CrossRef]

10. Johanness, R.E.; Wiebe, W.J.; Crossland, C.J.; Rimmer, D.W.; Smith, S.V. Latitudinal limits of coral reef growth. Mar. Ecol. Prog. Ser. 1983, 11, 105-111. [CrossRef]

11. Rasher, D.; Hay, M.; Rasher, D.B.; Hay, M.E. Chemically rich seaweeds poison corals when not controlled by herbivores. Proc. Natl. Acad. Sci. USA 2010, 107, 9683-9688. [CrossRef] [PubMed]

12. Rasher, D.B.; Engel, S.; Bonito, V.; Fraser, G.J.; Montoya, J.P.; Hay, M.E. Effects of herbivory, nutrients, and reef protection on algal proliferation and coral growth on a tropical reef. Oecologia 2012, 169, 187-198. [CrossRef] 
13. Harrington, L.; Fabricius, K.; De'Ath, G.; Negri, A. Recognition and selection of settlement substrata determine post-settlement survival in corals. Ecology 2004, 85, 3428-3437. [CrossRef]

14. Morse, A.N.C.; Morse, D.E. Flypapers for Coral and Other Planktonic Larvae: New materials incorporate morphogens for applications in research, restoration, aquaculture, and medicine. BioScience 1996, 46, 254-262. [CrossRef]

15. LaJeunesse, T.; Parkinson, J.; Gabrielson, P.; Jeong, H.J.; Reimer, J.; Voolstra, C.; Santos, S. Systematic Revision of Symbiodiniaceae Highlights the Antiquity and Diversity of Coral Endosymbionts. Curr. Biol. 2018, 28, 2570-2580. [CrossRef]

16. Goulet, T.L. Most corals may not change their symbionts. Mar. Ecol. Prog. Ser. 2006, 321, 1-7. [CrossRef]

17. Thornhill, D.J.; Howells, E.J.; Wham, D.C.; Steury, T.D.; Santos, S.R. Population genetics of reef coral endosymbionts (Symbiodinium, Dinophyceae). Mol. Ecol. 2017, 26, 2640-2659. [CrossRef] [PubMed]

18. Thornhill, D.J.; Lewis, A.M.; Wham, D.C.; LaJeunesse, T.C. Host-specialist lineages dominate the adaptive radiation of reef coral endosymbionts. Evolution 2014, 68, 352-367. [CrossRef]

19. Baird, A.H.; Cumbo, V.R.; Leggat, W.; Rodriguez-Lanetty, M. Fidelity and flexibility in coral symbioses. Mar. Ecol. Prog. Ser. 2007, 347, 307-309. [CrossRef]

20. Wicks, L.C.; Sampayo, E.; Gardner, J.P.A.; Davy, S.K. Local endemicity and high diversity characterise high-latitude coralSymbiodinium partnerships. Coral Reefs 2010, 29, 989-1003. [CrossRef]

21. Keith, S.A.; Herbert, R.J.H.; Norton, P.A.; Hawkins, S.J.; Newton, A.C. Individualistic species limitations of climate-induced range expansions generated by meso-scale dispersal barriers. Divers. Distrib. 2011, 17, 275-286. [CrossRef]

22. Sommer, B.; Harrison, P.; Beger, M.; Pandolfi, J. Trait-mediated environmental filtering drives assembly at biogeographic transition zones. Ecology 2014, 95, 1000-1009. [CrossRef]

23. Vamosi, S.M.; Mazer, S.J.; Cornejo, F. Breeding systems and seed size in a neotropical flora: Testing evolutionary hypotheses. Ecology 2008, 89, 2461-2472. [CrossRef]

24. Baird, A.H.; Guest, J.R.; Willis, B.L. Systematic and Biogeographical Patterns in the Reproductive Biology of Scleractinian Corals. Annu. Rev. Ecol. Evol. Syst. 2009, 40, 551-571. [CrossRef]

25. Figueiredo, J.; Baird, A.; Harii, S.; Connolly, S. Increased local retention of reef coral larvae as a result of ocean warming. Nat. Clim. Chang. 2014, 4, 498-502. [CrossRef]

26. Mizerek, T.L.; Madin, J.S.; Benzoni, F.; Huang, D.; Luiz, O.J.; Mera, H.; Schmidt-Roach, S.; Smith, S.D.A.; Sommer, B.; Baird, A.H. No evidence for tropicalization of coral assemblages in a subtropical climate change hot spot. Coral Reefs 2021, 40, $1451-1461$. [CrossRef]

27. Greenstein, B.; Pandolfi, J. Escaping the heat: Range shifts of reef coral taxa in coastal Western Australia. Glob. Chang. Biol. 2008, 14, 513-528. [CrossRef]

28. Kiessling, W.; Simpson, C.; Beck, B.; Mewis, H.; Pandolfi, J.M. Equatorial decline of reef corals during the last Pleistocene interglacial. Proc. Natl. Acad. Sci. USA 2012, 109, 21378-21383. [CrossRef] [PubMed]

29. Beger, M.; Sommer, B.; Harrison, P.L.; Smith, S.D.A.; Pandolfi, J.M. Conserving potential coral reef refuges at high latitudes. Divers. Distrib. 2014, 20, 245-257. [CrossRef]

30. Camp, E.F.; Schoepf, V.; Mumby, P.J.; Hardtke, L.A.; Rodolfo-Metalpa, R.; Smith, D.J.; Suggett, D.J. The Future of Coral Reefs Subject to Rapid Climate Change: Lessons from Natural Extreme Environments. Front. Mar. Sci. 2018, 5, 4. [CrossRef]

31. Abrego, D.; Baird, A.; Howells, E.; Smith, S. Pools of resilience. Bull. Mar. Sci. 2021. accepted. [CrossRef]

32. Precht, W.; Aronson, R. Climate Flickers and Range Shifts of Reef Corals. Front. Ecol. Environ. 2004, 2, 307-314. [CrossRef]

33. Yamano, H.; Sugihara, K.; Nomura, K. Rapid poleward range expansion of tropical reef corals in response to rising sea surface temperatures. Geophys. Res. Lett. 2011, 38, L04601. [CrossRef]

34. Dalton, S.J.; Roff, G. Spatial and Temporal Patterns of Eastern Australia Subtropical Coral Communities. PLoS ONE 2013, 8, e75873 [CrossRef] [PubMed]

35. Sommer, B.; Sampayo, E.; Beger, M.; Harrison, P.; Babcock, R.; Pandolfi, J. Local and regional controls of phylogenetic structure at the high-latitude range limits of corals. Proc. R. Soc. B Biol. Sci. 2017, 284, 20170915. [CrossRef] [PubMed]

36. Hughes, T.P.; Anderson, K.D.; Connolly, S.R.; Heron, S.F.; Kerry, J.T.; Lough, J.M.; Baird, A.H.; Baum, J.K.; Berumen, M.L.; Bridge, T.C.; et al. Spatial and temporal patterns of mass bleaching of corals in the Anthropocene. Science 2018, 359, 80-83. [CrossRef]

37. Fraser, R.H.; Currie, D.J. The Species Richness-Energy Hypothesis in a System Where Historical Factors Are Thought to Prevail: Coral Reefs. Am. Nat. 1996, 148, 138-159. [CrossRef]

38. Harriott, V.; Banks, S. Latitudinal variation in coral communities in eastern Australia: A qualitative biophysical model of factors regulating coral reefs. Coral Reefs 2002, 21, 83-94. [CrossRef]

39. Kumagai, N.H.; García Molinos, J.; Yamano, H.; Takao, S.; Fujii, M.; Yamanaka, Y. Ocean currents and herbivory drive macroalgaeto-coral community shift under climate warming. Proc. Natl. Acad. Sci. USA 2018, 115, 8990-8995. [CrossRef]

40. Sommer, B.; Beger, M.; Harrison, P.L.; Babcock, R.C.; Pandolfi, J.M. Differential response to abiotic stress controls species distributions at biogeographic transition zones. Ecography 2018, 41, 478-490. [CrossRef]

41. Tuckett, C.A.; Wernberg, T. High Latitude Corals Tolerate Severe Cold Spell. Front. Mar. Sci. 2018, 5, 14. [CrossRef]

42. Veron, J.E.N. Southern geographic limits to the distribution of Great Barrier Reef hermatypic corals. In Proceedings of the 2nd International Coral Reef Symposium, Brisbane, Australia, 22 June-2nd July 1973; Great Barrier Reef Committee: Brisbane, Australia, 1974; pp. 465-474. 
43. Coles, S.L.; Fadlallah, Y.H. Reef coral survival and mortality at low temperatures in the Arabian Gulf: New species-specific lower temperature limits. Coral Reefs 1991, 9, 231-237. [CrossRef]

44. Kemp, D.W.; Oakley, C.A.; Thornhill, D.J.; Newcomb, L.A.; Schmidt, G.W.; Fitt, W.K. Catastrophic mortality on inshore coral reefs of the Florida Keys due to severe low-temperature stress. Glob. Chang. Biol. 2011, 17, 3468-3477. [CrossRef]

45. Tracey, S.; William, C.D.; Ove, H.-G. Photosynthetic responses of the coral Montipora digitata to cold temperature stress. Mar. Ecol. Prog. Ser. 2003, 248, 85-97.

46. Leriorato, J.C.; Nakamura, Y. Unpredictable extreme cold events: A threat to range-shifting tropical reef fishes in temperate waters. Mar. Biol. 2019, 166, 110. [CrossRef]

47. McIlroy, S.E.; Thompson, P.D.; Yuan, F.L.; Bonebrake, T.C.; Baker, D.M. Subtropical thermal variation supports persistence of corals but limits productivity of coral reefs. Proc. R. Soc. B 2019, 286, 20190882. [CrossRef]

48. Malcolm, H.A.; Davies, P.L.; Jordan, A.; Smith, S.D.A. Variation in sea temperature and the East Australian Current in the Solitary Islands region between 2001-2008. Deep. Sea Res. Part II Top. Stud. Oceanogr. 2011, 58, 616-627. [CrossRef]

49. Jurriaans, S.; Hoogenboom, M.O. Seasonal acclimation of thermal performance in two species of reef-building corals. Mar. Ecol. Prog. Ser. 2020, 635, 55-70. [CrossRef]

50. Jurriaans, S.; Hoogenboom, M.O.; Ferrier-Pages, C. Similar thermal breadth of two temperate coral species from the Mediterranean Sea and two tropical coral species from the Great Barrier Reef. Coral Reefs 2021, 40, 1281-1295. [CrossRef]

51. Muscatine, L. Nutrition of corals. In Biology and Geology of Coral Reefs; Jones, O.A., Endean, R., Eds.; Academic Press: New York, NY, USA, 1973; Volume 2, pp. 77-115.

52. Done, T. Coral zonation: Its nature and significance. In Perspectives on Coral Reefs; Barnes, D.J., Ed.; Australian Institute of Marine Science: Townsville, QLD, Australia, 1983; pp. 107-147.

53. Roberts, T.E.; Keith, S.A.; Rahbek, C.; Bridge, T.C.L.; Caley, M.J.; Baird, A.H. Testing biodiversity theory using species richness of reef-building corals across a depth gradient. Biol. Lett. 2019, 15, 20190493. [CrossRef]

54. Kahng, S.; Hochberg, E.; Apprill, A.; Wagner, D.; Luck, D.G.; Perez, D.; Bidigare, R. Efficient light harvesting in deep-water zooxanthellate corals. Mar. Ecol. Prog. Ser. 2012, 455, 65-77. [CrossRef]

55. Williams, G.J.; Sandin, S.A.; Zgliczynski, B.J.; Fox, M.D.; Gove, J.M.; Rogers, J.S.; Furby, K.A.; Hartmann, A.C.; Caldwell, Z.R.; Price, N.N.; et al. Biophysical drivers of coral trophic depth zonation. Mar. Biol. 2018, 165, 60. [CrossRef]

56. Anthony, K.R.N.; Hoogemboom, M.O.; Connolly, S.R. Adaptive variation in coral geometry and the optimization of internal colony light climates. Funct. Ecol. 2005, 19, 17-26. [CrossRef]

57. Edmunds, P.J. The role of colony morphology and substratum inclination in the success of Millepora alcicornis on shallow coral reefs. Coral Reefs 1999, 18, 133-140. [CrossRef]

58. Baird, A.; Abrego, D. Troglodyte Turbinaria in the intertidal rock pools of the Solitary Islands Marine Park. Galaxea J. Coral Reef Stud. 2021, 23, 9-10. [CrossRef]

59. Fantazzini, P.; Mengoli, S.; Pasquini, L.; Bortolotti, V.; Brizi, L.; Mariani, M.; Di Giosia, M.; Fermani, S.; Capaccioni, B.; Caroselli, E.; et al. Gains and losses of coral skeletal porosity changes with ocean acidification acclimation. Nat. Commun. 2015, 6, 7785. [CrossRef] [PubMed]

60. Foster, T.; Flater, J.L.; McCulloch, M.T.; Clode, P.L. Ocean acidification causes structural deformities in juvenile coral skeletons. Sci. Adv. 2016, 2, e1501130. [CrossRef]

61. Tambutté, E.; Venn, A.A.; Holcomb, M.; Segonds, N.; Techer, N.; Zoccola, D.; Allemand, D.; Tambutté, S. Morphological plasticity of the coral skeleton under CO2-driven seawater acidification. Nat. Commun. 2015, 6, 7368. [CrossRef]

62. Manzello, D. Coral growth with thermal stress and ocean acidification: Lessons from the eastern tropical Pacific. Coral Reefs 2010, 29, 749-758. [CrossRef]

63. Eyre, B.D.; Cyronak, T.; Drupp, P.; De Carlo, E.H.; Sachs, J.P.; Andersson, A.J. Coral reefs will transition to net dissolving before end of century. Science 2018, 359, 908-911. [CrossRef]

64. Doropoulos, C.; Ward, S.; Diaz-Pulido, G.; Hoegh-Guldberg, O.; Mumby, P.J. Ocean acidification reduces coral recruitment by disrupting intimate larval-algal settlement interactions. Ecol. Lett. 2012, 15, 338-346. [CrossRef]

65. Diaz-Pulido, G.; Gouezo, M.; Tilbrook, B.; Dove, S.; Anthony, K.R.N. High CO2 enhances the competitive strength of seaweeds over corals. Ecol. Lett. 2011, 14, 156-162. [CrossRef] [PubMed]

66. Reyes-Nivia, C.; Diaz-Pulido, G.; Kline, D.; Guldberg, O.-H.; Dove, S. Ocean acidification and warming scenarios increase microbioerosion of coral skeletons. Glob. Chang. Biol. 2013, 19, 1919-1929. [CrossRef]

67. Tribollet, A.; Godinot, C.; Atkinson, M.; Langdon, C. Effects of elevated pCO2 on dissolution of coral carbonates by microbial euendoliths. Glob. Biogeochem. Cycles 2009, 23, GB3008. [CrossRef]

68. Orr, J.C.; Fabry, V.J.; Aumont, O.; Bopp, L.; Doney, S.C.; Feely, R.A.; Gnanadesikan, A.; Gruber, N.; Ishida, A.; Joos, F.; et al. Anthropogenic ocean acidification over the twenty-first century and its impact on calcifying organisms. Nature 2005, 437, 681-686. [CrossRef] [PubMed]

69. Kleypas, J.A.; Buddemeier, R.W.; Archer, D.; Gattuso, J.P.; Langdon, C.; Opdyke, B.N. Geochemical consequences of increased atmospheric carbon dioxide on coral reefs. Science 1999, 284, 118-120. [CrossRef]

70. Barros, V.R.; Fields, C.B. Climate Change 2014: Impacts, adaptations, and vulnerability. Part B: Regional aspects. In Contribution of Working Group II to the 5th Assessment Report of the IPCC; Cambridge University Press: New York, NY, USA, 2014; pp. 1133-1197. 
71. Hughes, T.P.; Barnes, M.L.; Bellwood, D.R.; Cinner, J.E.; Cumming, G.S.; Jackson, J.B.C.; Kleypas, J.; van de Leemput, I.A.; Lough, J.M.; Morrison, T.H.; et al. Coral reefs in the Anthropocene. Nature 2017, 546, 82. [CrossRef]

72. Comeau, S.; Edmunds, P.J.; Spindel, N.B.; Carpenter, R.C. Fast coral reef calcifiers are more sensitive to ocean acidification in short-term laboratory incubations. Limnol. Oceanogr. 2014, 59, 1081-1091. [CrossRef]

73. Maier, C.; Watremez, P.; Taviani, M.; Weinbauer, M.G.; Gattuso, J.P. Calcification rates and the effect of ocean acidification on Mediterranean cold-water corals. Proc. R. Soc. B 2012, 279, 1716-1723. [CrossRef] [PubMed]

74. McCulloch, M.; Falter, J.; Trotter, J.; Montagna, P. Coral resilience to ocean acidification and global warming through $\mathrm{pH}$ up-regulation. Nat. Clim. Chang. 2012, 2, 623-627. [CrossRef]

75. Thresher, R.E.; Tilbrook, B.; Fallon, S.; Wilson, N.C.; Adkins, J. Effects of chronic low carbonate saturation levels on the distribution, growth and skeletal chemistry of deep-sea corals and other seamount megabenthos. Mar. Ecol. Prog. Ser. 2011, 442, 87-99. [CrossRef]

76. Boyd, P.W.; Collins, S.; Dupont, S.; Fabricius, K.; Gattuso, J.-P.; Havenhand, J.; Hutchins, D.A.; Riebesell, U.; Rintoul, M.S.; Vichi, M.; et al. Experimental strategies to assess the biological ramifications of multiple drivers of global ocean change- $\mathrm{A}$ review. Glob. Chang. Biol. 2018, 24, 2239-2261. [CrossRef]

77. Heinze, C.; Blenckner, T.; Martins, H.; Rusiecka, D.; Döscher, R.; Gehlen, M.; Gruber, N.; Holland, E.; Hov, Ø.; Joos, F.; et al. The quiet crossing of ocean tipping points. Proc. Natl. Acad. Sci. USA 2021, 118, e2008478118. [CrossRef] [PubMed]

78. Rogers, C. Responses of coral reefs and reef organisms to sedimentation. Mar. Ecol. Prog. Ser. 1990, 62, 185-202. [CrossRef]

79. Wilson, B. Chapter 1-Introduction. In The Biogeography of the Australian North West Shelf; Wilson, B., Ed.; Elsevier: Boston, MA, USA, 2013; pp. 1-12.

80. Sanders, D.; Baron-Szabo, R. Scleractinian assemblages under sediment input: Their characteristics and relation to the nutrient input concept. Palaeogeogr. Palaeoclimatol. Palaeoecol. 2005, 216, 139-181. [CrossRef]

81. Junjie, R.; Browne, N.; Erftemeijer, P.; Todd, P. Impacts of Sediments on Coral Energetics: Partitioning the Effects of Turbidity and Settling Particles. PLoS ONE 2014, 9, e107195. [CrossRef]

82. Ricardo, G.F.; Jones, R.J.; Clode, P.L.; Humanes, A.; Giofre, N.; Negri, A.P. Sediment characteristics influence the fertilisation success of the corals Acropora tenuis and Acropora millepora. Mar. Pollut. Bull. 2018, 135, 941-953. [CrossRef]

83. Storlazzi, C.D.; Norris, B.K.; Rosenberger, K.J. The influence of grain size, grain color, and suspended-sediment concentration on light attenuation: Why fine-grained terrestrial sediment is bad for coral reef ecosystems. Coral Reefs 2015, 34, 967-975. [CrossRef]

84. Morgan, K.M.; Perry, C.T.; Smithers, S.G.; Johnson, J.A.; Daniell, J.J. Evidence of extensive reef development and high coral cover in nearshore environments: Implications for understanding coral adaptation in turbid settings. Sci. Rep. 2016, 6, 29616. [CrossRef]

85. Richards, Z.T.; Garcia, R.A.; Wallace, C.C.; Rosser, N.L.; Muir, P.R. A Diverse Assemblage of Reef Corals Thriving in a Dynamic Intertidal Reef Setting (Bonaparte Archipelago, Kimberley, Australia). PLoS ONE 2015, 10, e0117791. [CrossRef]

86. Mies, M.; Francini-Filho, R.B.; Zilberberg, C.; Garrido, A.G.; Longo, G.O.; Laurentino, E.; Güth, A.Z.; Sumida, P.Y.G.; Banha, T.N.S South Atlantic Coral Reefs Are Major Global Warming Refugia and Less Susceptible to Bleaching. Front. Mar. Sci. 2020, 7, 514. [CrossRef]

87. Zweifler, A.; O’Leary, M.; Morgan, K.; Browne, N.K. Turbid Coral Reefs: Past, Present and Future-A Review. Diversity 2021, 13, 251. [CrossRef]

88. Anthony, K.R.N. Coral suspension feeding on fine particulate matter. J. Exp. Mar. Biol. Ecol. 1999, 232, 85-106. [CrossRef]

89. Anthony, K.R.N.; Fabricius, K.E. Shifting roles of heterotrophy and autotrophy in coral energetics under varying turbidity. J. Exp. Mar. Biol. Ecol. 2000, 252, 221-253. [CrossRef]

90. Ezzat, L.; Maguer, J.-F.; Grover, R.; Rottier, C.; Tremblay, P.; Ferrier-Pagès, C. Nutrient starvation impairs the trophic plasticity of reef-building corals under ocean warming. Funct. Ecol. 2019, 33, 643-653. [CrossRef]

91. Tremblay, P.; Gori, A.; Maguer, J.F.; Hoogenboom, M.; Ferrier-Pagès, C. Heterotrophy promotes the re-establishment of photosynthate translocation in a symbiotic coral after heat stress. Sci. Rep. 2016, 6, 38112. [CrossRef] [PubMed]

92. Sarmiento, J.L.; Gruber, N.; Brzezinski, M.A.; Dunne, J.P. High-latitude controls of thermocline nutrients and low latitude biological productivity. Nature 2004, 427, 56-60. [CrossRef] [PubMed]

93. Crossland, C.J.; Hatcher, B.G.; Atkinson, M.J.; Smith, S.V. Dissolved nutrients of a high-latitude coral reef, Houtman Abrolhos Islands, Western Australia. Mar. Ecol. Prog. Ser. 1984, 14, 159-163. [CrossRef]

94. Marubini, F.; Davies, P.S. Nitrate increases zooxanthellae population density and reduces skeletogenesis in corals. Mar. Biol. 1996, 127, 319-328. [CrossRef]

95. Langdon, C.; Atkinson, M. Effect of elevated pCO2 on photosynthesis and calcification of corals and interactions with seasonal change in temperature/irradiance and nutrient enrichment. J. Geophys. Res. 2005, 110, C09S07. [CrossRef]

96. Ferrier-Pagès, C.; Gattuso, J.P.; Dallot, S.; Jaubert, J. Effect of nutrient enrichment on growth and photosynthesis of the zooxanthellate coral Stylophora pistillata. Coral Reefs 2000, 19, 103-113. [CrossRef]

97. Kinsey, D.W.; Davies, P.J. Effects of elevated nitrogen and phosphorus on coral reef growth1. Limnol. Oceanogr. 1979, 24, 935-940. [CrossRef]

98. Ezzat, L.; Maguer, J.-F.; Grover, R.; Ferrier-Pagès, C. Limited phosphorus availability is the Achilles heel of tropical reef corals in a warming ocean. Sci. Rep. 2016, 6, 31768. [CrossRef]

99. Monismith, S.G. Hydrodynamics of Coral Reefs. Annu. Rev. Fluid Mech. 2007, 39, 37-55. [CrossRef] 
100. Willis, B.L.; Oliver, J.K. Direct tracking of coral larvae: Implications for dispersal studies of planktonic larvae in topographically complex environments. Ophelia 1990, 32, 145-162. [CrossRef]

101. Harii, S.; Kayanne, H.; Takigawa, H.; Hayashibara, T.; Yamamoto, M. Larval survivorship competency periods and settlement of two brooding corals, Heliopora coerulea and Pocillopora damicornis. Mar. Biol. 2002, 141, 39-46.

102. Hata, T.; Madin, J.S.; Cumbo, V.R.; Denny, M.; Figueiredo, J.; Harii, S.; Thomas, C.J.; Baird, A.H. Coral larvae are poor swimmers and require fine-scale reef structure to settle. Sci. Rep. 2017, 7, 2249. [CrossRef]

103. Stocking, J.B.; Laforsch, C.; Sigl, R.; Reidenbach, M.A. The role of turbulent hydrodynamics and surface morphology on heat and mass transfer in corals. J. R. Soc. Interface 2018, 15, 20180448. [CrossRef] [PubMed]

104. Lesser, M.P.; Weis, V.M.; Patterson, M.R.; Jokiel, P.L. Effects of morphology and water motion on carbon delivery and productivity in the reef coral, Pocillopora damicornis (Linnaeus): Diffusion barriers, inorganic carbon limitation, and biochemical plasticity. J. Exp. Mar. Biol. Ecol. 1994, 178, 153-179. [CrossRef]

105. Schutter, M.; Crocker, J.; Paijmans, A.; Janse, M.; Osinga, R.; Verreth, A.J.; Wijffels, R.H. The effect of different flow regimes on the growth and metabolic rates of the scleractinian coral Galaxea fascicularis. Coral Reefs 2010, 29, 737-748. [CrossRef]

106. Madin, J.S.; Connolly, S.R. Ecological consequences of major hydrodynamic disturbances on coral reefs. Nature 2006, 444, 477-480. [CrossRef] [PubMed]

107. Chesson, P. General Theory of Competitive Coexistence in Spatially-Varying Environments. Theor. Popul. Biol. 2000, 58, 211-237. [CrossRef] [PubMed]

108. Connell, J.H. Diversity in Tropical Rain Forests and Coral Reefs. Science 1978, 199, 1302-1310. [CrossRef]

109. Highsmith, R.C. Reproduction by Fragmentation in Corals. Mar. Ecol. Prog. Ser. 1982, 7, 207-226. [CrossRef]

110. Smith, L.D.; Hughes, T.P. An experimental assessment of survival, re-attachment and fecundity of coral fragments. J. Exp. Mar. Biol. Ecol. 1999, 235, 147-164. [CrossRef]

111. Tunnicliffe, V. Breakage and propagation of the stony coral Acropora cervicornis. Proc. Natl. Acad. Sci. USA 1981, 78, $2427-2431$. [CrossRef]

112. Rasser, M.; Riegl, B. Holocene coral reef rubble and its binding agents. Coral Reefs 2002, 21, 57-72. [CrossRef]

113. Madin, J.; Dell, A.; Madin, E.; Nash, M. Spatial variation in mechanical properties of coral reef substrate and implications for coral colony integrity. Coral Reefs 2012, 32, 173-179. [CrossRef]

114. Done, T.J. Patterns in the distribution of coral communities across the central Great Barrier Reef. Coral Reefs 1982, 1, 95-107. [CrossRef]

115. Eagle, J.; Baird, A.; Jones, G.; Kingsford, M. Recruitment hotspots: Consistent spatial patterns in the relative abundance of coral recruits at One Tree Island Australia. Galaxea 2012, 14, 5-22. [CrossRef]

116. Maida, M.; Coll, J.C.; Sammarco, P.W. Shedding new light on scleractinian coral recruitment. J. Exp. Mar. Biol. Ecol. 1994, 180, 189-202. [CrossRef]

117. Viehman, S.; Hench, J.L.; Griffin, S.P.; Malhotra, A.; Egan, K.; Halpin, P.N. Understanding differential patterns in coral reef recovery: Chronic hydrodynamic disturbance as a limiting mechanism for coral colonization. Mar. Ecol. Prog. Ser. 2018, 605, 135-150. [CrossRef]

118. Massel, S.R.; Done, T.J. Effects of cyclone waves on massive coral assemblages on the Great Barrier Reef: Meteorology, hydrodynamics and demography. Coral Reefs 1993, 12, 153-166. [CrossRef]

119. Sebens, K.P.; Grace, S.P.; Helmuth, B.; Maney, E.J., Jr.; Miles, J.S. Water flow and prey capture by three scleractinian corals, Madracis mirabilis, Montastrea cavernosa and Porites porites, in a field enclosure. Mar. Biol. 1998, 131, 347-360. [CrossRef]

120. Harriott, V.J.; Smith, S.D.A.; Harrison, P.L. Patterns of coral community structure of subtropical reefs in the Solitary Islands Marine Reserve, Eastern Australia. Mar. Ecol. Prog. Ser. 1994, 109, 67-76. [CrossRef]

121. Ross, C.L.; Falter, J.L.; Schoepf, V.; McCulloch, M.T. Perennial growth of hermatypic corals at Rottnest Island, Western Australia (32 ${ }^{\circ}$ S). PeerJ 2015, 3, e781. [CrossRef] [PubMed]

122. Yamano, H.; Sugihara, K.; Watanabe, T.; Shimamura, M.; Hyeong, K. Coral reefs at $34^{\circ}$ N, Japan: Exploring the end of environmental gradients. Geology 2012, 40, 835-838. [CrossRef]

123. Fairley, I.; Lewis, M.; Robertson, B.; Hemer, M.; Masters, I.; Horrillo-Caraballo, J.; Karunarathna, H.; Reeve, D.E. A classification system for global wave energy resources based on multivariate clustering. Appl. Energy 2020, 262, 114515. [CrossRef]

124. Knutson, T.R.; McBride, J.L.; Chan, J.; Emanuel, K.; Holland, G.; Landsea, C.; Held, I.; Kossin, J.P.; Srivastava, A.K.; Sugi, M. Tropical cyclones and climate change. Nat. Geosci. 2010, 3, 157-163. [CrossRef]

125. Miller, K.J.; Ayre, D.J. The role of sexual and asexual reproduction in structuring high latitude populations of the reef coral Pocillopora damicornis. Heredity 2004, 92, 557-568. [CrossRef]

126. Noreen, A.M.E.; Harrison, P.L.; Van Oppen, M.J.H. Genetic diversity and connectivity in a brooding reef coral at the limit of its distribution. Proc. R. Soc. B 2009, 276, 3927-3935. [CrossRef]

127. Miller, K.J.; Ayre, D.J. Protection of genetic diversity and maintenance of connectivity among reef corals within marine protected areas. Conserv. Biol. J. Soc. Conserv. Biol. 2008, 22, 1245-1254. [CrossRef] [PubMed]

128. Schmidt-Roach, S.; Miller, K.J.; Andreakis, N. Pocillopora aliciae: A new species of scleractinian coral (Scleractinia, Pocilloporidae) from subtropical Eastern Australia. Zootaxa 2013, 3626, 576-582. [CrossRef] [PubMed] 
129. Noreen, A.M.E.; Schmidt-Roach, S.; Harrison, P.L.; van Oppen, M.J.H. Diverse associations among coral host haplotypes and algal endosymbionts may drive adaptation at geographically peripheral and ecologically marginal locations. J. Biogeogr. 2015, 42, 1639-1650. [CrossRef]

130. Graham, E.; Baird, A.; Connolly, S. Survival dynamics of scleractinian coral larvae and implications for dispersal. Coral Reefs 2008, 27, 529-539. [CrossRef]

131. Noreen, A.; Van Oppen, M.J.; Harrison, P.L. Genetic diversity and differentiation among high-latitude broadcast-spawning coral populations disjunct from the core range. Mar. Ecol. Prog. Ser. 2013, 491, 101-109. [CrossRef]

132. Heyward, A.J.; Negri, A.P. Natural inducers for coral larval metamorphosis. Coral Reefs 1999, 18, 273-279. [CrossRef]

133. Morse, D.; Morse, A. Enzymatic characterization of the morphogen recognized by Agaricia humilis (scleractinian coral) larvae. Biol. Bull. 1991, 181, 104-122. [CrossRef]

134. Jorissen, H.; Galand, P.E.; Bonnard, I.; Meiling, S.; Raviglione, D.; Meistertzheim, A.-L.; Hédouin, L.; Banaigs, B.; Payri, C.E.; Nugues, M.M. Coral larval settlement preferences linked to crustose coralline algae with distinct chemical and microbial signatures. Sci. Rep. 2021, 11, 14610. [CrossRef]

135. Negri, A.P.; Webster, N.S.; Hill, R.T.; Heyward, A.J. Metamorphosis of broadcast spawning corals in response to bacteria isolated from crustose algae. Mar. Ecol.Prog. Ser. 2001, 223, 121-131. [CrossRef]

136. Siboni, N.; Abrego, D.; Puill-Stephan, E.; King, W.L.; Bourne, D.G.; Raina, J.-B.; Seymour, J.R.; Harder, T. Crustose coralline algae that promote coral larval settlement harbor distinct surface bacterial communities. Coral Reefs 2020, 39, 1703-1713. [CrossRef]

137. Tebben, J.; Tapiolas, D.M.; Motti, C.A.; Abrego, D.; Negri, A.P.; Blackall, L.L.; Steinberg, P.D.; Harder, T. Induction of Larval Metamorphosis of the Coral Acropora millepora by Tetrabromopyrrole Isolated from a Pseudoalteromonas Bacterium. PLoS ONE 2011, 6, e19082. [CrossRef]

138. Tran, C.; Hadfield, M. Larvae of Pocillopora damicornis (Anthozoa) settle and metamorphose in response to surface-biofilm bacteria. Mar. Ecol. Prog. Ser. 2011, 433, 85-96. [CrossRef]

139. Webster, N.S.; Smith, L.; Heyward, A.; Watts, E.; Webb, R.; Blackall, L.; Negri, A.P. Metamorphosis of a scleractinian coral in response to microbial biofilms. Appl. Environ. Microbiol. 2004, 70, 1213-1221. [CrossRef] [PubMed]

140. Ritson-Williams, R.; Arnold, S.N.; Paul, V.J. Patterns of larval settlement preferences and post-settlement survival for seven Caribbean corals. Mar. Ecol. Prog. Ser. 2016, 548, 127-138. [CrossRef]

141. Nozawa, Y.; Tokeshi, M.; Nojima, S. Reproduction and recruitment of scleractinian corals in a high-latitude coral community, Amakusa, southwestern Japan. Mar. Biol. 2006, 149, 1047-1058. [CrossRef]

142. Harriott, V.; Harrison, P.; Banks, S. The coral communities of Lord Howe Island. Mar. Freshw. Res. 1995, 46, 457-465. [CrossRef]

143. Gabrielson, P.W.; Hughey, J.R.; Diaz-Pulido, G. Genomics reveals abundant speciation in the coral reef building alga Porolithon onkodes (Corallinales, Rhodophyta). J. Phycol. 2018, 54, 429-434. [CrossRef]

144. Twist, B.A.; Neill, K.F.; Bilewitch, J.; Jeong, S.Y.; Sutherland, J.E.; Nelson, W.A. High diversity of coralline algae in New Zealand revealed: Knowledge gaps and implications for future research. PLoS ONE 2019, 14, e225645. [CrossRef] [PubMed]

145. LaJeunesse, T.C.; Loh, W.K.W.; van Woesik, R.; Hoegh-Guldberg, O.; Schmidt, G.W.; Fitt, W.K. Low symbiont diversity in southern Great Barrier Reef corals, relative to those of the Caribbean. Limonology Oceanogr. 2003, 48, 2046-2054. [CrossRef]

146. LaJeunesse, T.C.; Bhagooli, R.; Hidaka, M.; de Vantier, L.; Done, T.; Schmidt, G.W.; Fitt, W.K.; Hoegh-Guldberg, O. Closely related Symbiodinium spp. differ in relative dominance in coral reef host communities across environmental, latitudinal and biogeographic gradients. Mar. Ecol. Prog. Ser. 2004, 284, 147-161. [CrossRef]

147. Chen, B.; Yu, K.; Liang, J.; Huang, W.; Wang, G.; Su, H.; Qin, Z.; Huang, X.; Pan, Z.; Luo, W.; et al. Latitudinal Variation in the Molecular Diversity and Community Composition of Symbiodiniaceae in Coral From the South China Sea. Front. Microbiol. 2019, 10, 1278. [CrossRef]

148. Sampayo, E.M.; Franceschinis, L.; Hoegh-Guldberg, O.; Dove, S. Niche partitioning of closely related symbiotic dinoflagellates. Mol. Ecol. 2007, 16, 3721-3733. [CrossRef] [PubMed]

149. Pontasch, S.; Scott, A.; Hill, R.; Bridge, T.; Fisher, P.; Davy, S. Symbiodinium diversity in the sea anemone Entacmaea quadricolor on the east Australian coast. Coral Reefs 2014, 33, 537-542. [CrossRef]

150. Rodriguez-Lanetty, M.; Loh, W.; Carter, D.; Hoegh-Guldberg, O. Latitudinal variability in symbiont specificity within the widespread scleractinian coral Plesiastrea versipora. Mar. Biol. 2001, 138, 1175-1181.

151. Silverstein, R.; Correa, A.; LaJeunesse, T.; Baker, A. Novel algal symbiont (Symbiodinium spp.) diversity in reef corals of Western Australia. Mar. Ecol. Prog. Ser. 2011, 422, 63-75. [CrossRef]

152. Thomas, L.; Kendrick, G.A.; Kennington, W.J.; Richards, Z.T.; Stat, M. Exploring Symbiodinium diversity and host specificity in Acropora corals from geographical extremes of Western Australia with 454 amplicon pyrosequencing. Mol. Ecol. 2014, 23, 3113-3126. [CrossRef]

153. Macdonald, A.H.H.; Sampayo, E.M.; Ridgway, T.; Schleyer, M.H. Latitudinal symbiont zonation in Stylophora pistillata from southeast Africa. Mar. Biol. 2008, 154, 209-217. [CrossRef]

154. Cowman, P.F.; Quattrini, A.M.; Bridge, T.C.L.; Watkins-Colwell, G.J.; Fadli, N.; Grinblat, M.; Roberts, T.E.; McFadden, C.S.; Miller, D.J.; Baird, A.H. An enhanced target-enrichment bait set for Hexacorallia provides phylogenomic resolution of the staghorn corals (Acroporidae) and close relatives. Mol. Phylogenetics Evol. 2020, 153, 106944. [CrossRef]

155. Howells, E.J.; Bauman, A.G.; Vaughan, G.O.; Hume, B.C.C.; Voolstra, C.R.; Burt, J.A. Corals in the hottest reefs in the world exhibit symbiont fidelity not flexibility. Mol. Ecol. 2020, 29, 899-911. [CrossRef] 
156. Thornhill, D.J.; Kemp, D.W.; Bruns, B.U.; Fitt, W.K.; Schmidt, G.W. Correspondence between cold tolerance and temperate biogeography in a Western Altantic Symbiodinium (Dinophyta) lineage. J. Phycol. 2008, 44, 1126-1135. [CrossRef]

157. Coffroth, M.A.; Poland, D.M.; Petrou, E.L.; Brazeau, D.A.; Holmberg, J.C. Environmental Symbiont Acquisition May Not Be the Solution to Warming Seas for Reef-Building Corals. PLoS ONE 2010, 5, e13258. [CrossRef]

158. Howells, E.J.; Abrego, D.; Meyer, E.; Kirk, N.L.; Burt, J.A. Host adaptation and unexpected symbiont partners enable reef-building corals to tolerate extreme temperatures. Glob. Chang. Biol. 2016, 22, 2702-2714. [CrossRef] [PubMed]

159. Abrego, D.; Willis, B.L.; van Oppen, M.J.H. Impact of Light and Temperature on the Uptake of Algal Symbionts by Coral Juveniles. PLOS ONE 2012, 7, e50311.

160. Mieog, J.C.; Olsen, J.L.; Berkelmans, R.; Bleuler-Martinez, S.A.; Willis, B.L.; Van Oppen, M.J.H. The roles and interactions of symbiont, host and environment in defining coral fitness. PLoS ONE 2009, 4, e6364. [CrossRef]

161. Peixoto, R.S.; Rosado, P.M.; Leite, D.C.d.A.; Rosado, A.S.; Bourne, D.G. Beneficial Microorganisms for Corals (BMC): Proposed Mechanisms for Coral Health and Resilience. Front. Microbiol. 2017, 8, 341. [CrossRef] [PubMed]

162. van Oppen, M.J.H.; Blackall, L.L. Coral microbiome dynamics, functions and design in a changing world. Nat. Rev. Microbiol. 2019, 17, 557-567. [CrossRef] [PubMed]

163. Hernandez-Agreda, A.; Legatt, W.; Bongaerts, P.; Ainsworth, T.D. The Microbial Signature Provides Insight into the Mechanistic Basis of Coral Success across Reef Habitats. mBio 2016, 7, e00560-16. [CrossRef] [PubMed]

164. McDevitt-Irwin, J.M.; Baum, J.K.; Garren, M.; Vega Thurber, R.L. Responses of Coral-Associated Bacterial Communities to Local and Global Stressors. Front. Mar. Sci. 2017, 4, 262. [CrossRef]

165. Fairfull, S.J.L.; Harriott, V.J. Succession, space and coral recruitment in a subtropical fouling community. Mar. Freshw. Res. 1999, 50, 235-242. [CrossRef]

166. Risk, M. Assessing the effects of sediments and nutrients on coral reefs. Curr. Opin. Environ. Sustain. 2014, 7, 108-117. [CrossRef]

167. Zabala, M.; Ballesteros, E.S. Surface-dependent strategies and energy flux in benthic marine communities or, why corals do not exist in the Mediterranean. Sci. Mar. 1989, 53, 3-17.

168. Harriott, V.; Smith, S. Coral population dynamics in a subtropical coral community, Solitary Islands Marine Park, Australia. In Proceedings of the 9th International Coral Reef Symposium, Bali, Indonesia, 23-27 October 2000; $2002 ;$ pp. $573-581$.

169. Vergés, A.; Doropoulos, C.; Malcolm, H.A.; Skye, M.; Garcia-Pizá, M.; Marzinelli, E.M.; Campbell, A.H.; Ballesteros, E.; Hoey, A.S.; Vila-Concejo, A.; et al. Long-term empirical evidence of ocean warming leading to tropicalization of fish communities, increased herbivory, and loss of kelp. Proc. Natl. Acad. Sci. USA 2016, 113, 13791-13796. [CrossRef] [PubMed]

170. Nimbs, M.J.; Smith, S.D.A. Beyond Capricornia: Tropical Sea Slugs (Gastropoda, Heterobranchia) Extend Their Distributions into the Tasman Sea. Diversity 2018, 10, 99. [CrossRef]

171. Nishi, E. Dense aggregation of Chaetopterus longipes Crosslan, 1904 (Chaetopteridae, Polychaeta) in coral reefs at Okinawa, Japan. Nat. Hist. Res. 1996, 4, 41-47.

172. Smith, S.D.A.; Harriot, V.J. Tube-building polychaete worms smother corals in the Solitary Islands Marine Park, northern NSW, Australia. Coral Reefs 1998, 17, 342. [CrossRef]

173. Kuguru, B.; Mgaya, Y.; Öhman, M.; Wagner, G. The reef environment and competitive success in the Corallimorpharia. Mar. Biol. 2004, 145, 875-884. [CrossRef]

174. Langmead, O.; Chadwick, N. Marginal tentacles of the corallimorpharian Rhodactis rhodostoma. 1. Role in competition for space. Mar. Biol. 1999, 134, 479-489. [CrossRef]

175. Adams, L.M.; Cumbo, V.R.; Takabayashi, M. Exposure to sediment enhances primary acquisition of Symbiodinium by asymbiotic coral larvae. Mar. Ecol. Prog. Ser. 2009, 377, 149-156. [CrossRef]

176. Cumbo, V.R.; van Oppen, M.J.H.; Baird, A.H. Temperature and Symbiodinium physiology affect the establishment and development of symbiosis in corals. Mar. Ecol. Prog. Ser. 2018, 587, 117-127. [CrossRef]

177. Venera-Ponton, D.E.; Diaz-Pulido, G.; Rodriguez-Lanetty, M.; Hoegh-Guldberg, O. Presence of Symbiodinium spp. in macroalgal microhabitats from the southern Great Barrier Reef. Coral Reefs 2010, 29, 1049-1060. [CrossRef]

178. Little, A.F.; van Oppen, M.J.H.; Willis, B.L. Flexibility in Algal Endosymbioses Shapes Growth in Reef Corals. Science 2004, 304, 1492-1494. [CrossRef] [PubMed]

179. Abrego, D.; Ulstrup, K.; Willis, B.; van Oppen, M. Species-specific interactions between algal endosymbionts and coral hosts define their bleaching response to heat and light stress. Proc. R. Soc. B 2008, 275, 2273-2282. [CrossRef] [PubMed] 